\title{
Erratum zu: Einleitung
}

\section{Erratum zu:}

\section{Kapitel 1 in: M. Schuster, Menschliches}

Verhalten im Wandel der Zeit, https://doi.org/10.1007/978-3-662-60698-8_1

Auf Seite 22 wurde versehentlich Literatur falsch zitiert. In Zeile 1 auf Seite 22 muss es richtig heißen:

Dilthey 1894 und im Literaturverzeichnis auf derselben Seite: Dilthey, W. (1894). Ideen über eine beschreibende und zergliedernde Psychologie. Berlin: Berliner Akademie. 